\title{
Solitary fibrous tumour of the pancreas: a case report
}

\section{Tumor fibroso solitario de páncreas: a propósito de un caso}

\author{
L. A. M. Santos ${ }^{1}$, V. M. Santos ${ }^{2}$, O. C. G. Oliveira ${ }^{3}$, M. De Marco ${ }^{4}$
}

\begin{abstract}
The solitary fibrous tumour is an uncommon neoplasm of mesenchymal origin. It occasionally develops in extra pleural locations, and is very infrequent in the pancreas. A 40-year-old woman had an unsuspected solitary fibrous tumour detected by chance in the body of the pancreas. Detection of the mass occurred with imaging studies. CT and MRI images showed the well-circumscribed benign lesion, with $3 \mathrm{~cm}$ on its greatest diameter. Treatment consisted of partial pancreatectomy, and her postoperative recovery was uneventful.
\end{abstract}

Key words. Diagnosis. Pancreas. Pancreatic neoplasma. Solitary fibrous tumor.

\section{RESUMEN}

El tumor fibroso solitario es una neoplasia poco común, de origen mesenquimal, que ocasionalmente se desarrolla en sitios extrapleurales, y es muy raro en el páncreas. Se presenta el caso de una mujer de 40 años, que presentó un tumor fibroso solitario descubierto por casualidad en el cuerpo del páncreas. La masa se observó con estudios de imagen. La lesión benigna, bien delimitada, con 3 centímetros de diámetro mayor, se descubrió en imágenes de CT y MRI. El tratamiento consistió en pancreatectomía parcial, y su recuperación postoperatoria no tuvo complicaciones.

Palabras clave. Diagnóstico. Páncreas. Neoplasma pancreático. Tumor fibroso solitario.
1. Surgery Department from State Workers Hospital (HSE), São Paulo-SP, Brazil

2. Catholic University (UCB) and Internal Medicine Department from Armed Forces Hospital (HFA), Brasília-DF, Brazil

3. Pathologist from Pathos Medical Diagnosis, São Paulo-SP, Brazil

4. Surgery Department from HSE, São Paulo-SP, Brazil

\section{Corresponding author:}

Vitorino Modesto dos Santos

Armed Forces Hospital.

Estrada do Contorno do Bosque $\mathbf{s} / \mathrm{n}$

Cruzeiro Novo, 70658-900

Brasília-DF, Brazil

E-mail: vitorinomodestos@gmail.com

Recepción: 30 de agosto de 2011

Aceptación provisional: 20 de octubre de 2011

Aceptación definitiva: 27 de octubre de 2011 


\section{INTRODUCTION}

Solitary fibrous tumor (SFT) is a very rare neoplasm of mesenchymal origin, characterized by the proliferation of fibroblastlike spindle cells and a variable component of hyalinized collagen ${ }^{1-9}$. Hypo and hyper cellular areas develop with anarchical arrangement of tumor cells in fascicles; while the fibrocollagen stroma shows variable hyalinization and may present numerous vessels $^{1,3}$. Extra abdominal SFT is reported in the pleura (65\%), lung, mediastinum, pericardium, meninges, orbit, oral cavity, salivary glands, nose, paranasal sinus, thyroid, diaphragm, breast, spinal cord, musculoskeletal system, vulva and vagina ${ }^{5,7}$. Intra abdominal STF has been described in the peritoneum, mesentery, adrenals, urogenital tract, stomach, and liver, but pancreatic location is exceeding rare $^{1-9}$. All tumors had benign histological features. There were four tumor ressections, three pancreatoduodenectomies, and two partial pancreatectomies ${ }^{1-9}$. Diagnosis cannot be established exclusively with base on clinical and imaging data, and suggestive histopathology features must be confirmed by immunoistochemical studies. SFTs are classically positive for CD34, bcl-2, vimentin and CD99, and negative for cytokeratins, smooth muscle actin, desmin, epithelial membrane antigen, S-100, HMB-45, as well as c-kit ${ }^{1,3,5-9}$. Case studies can contribute to increase the awareness about this scarcely reported condition.

\section{CASE REPORT}

A 40-year-old woman came to Hospital because of a gynecological affection. Her physical examination and routine laboratory data were within normal limits, including the tumor markers. She was submitted to CT and MRI pelvic and abdominal imaging studies, which incidentally revealed a rounded solid mass in the body of the pancreas. This unsuspected mass appeared well circumscribed, with $3 \mathrm{~cm}$ in its greatest diameter. Worth of note, no other remarkable change was detected in images of the abdominal cavity, and regional lymphadenopathy was not observed. The samples obtained from fine needle aspiration were not sufficient to establish the diagnosis. The patient was then submitted to a partial pancreatectomy, with uneventful postoperative course. Grossly, the tumor was solid with some cystic areas, pseudocapsulated and well delimited, surrounded by normal pancreas tissue. The histopathology analysis revealed that the boundaries between the SFT and normal pancreas tissue was clearly demarcated (Fig. 1A), and the focally hyalinized fusocellular growth showed a highly vascularized stroma (Fig. 1B). Neither cytonuclear atypias nor mitoses, or necrotic areas were observed, and the mass was considered of benign nature. On immunohistochemistry studies, the majority of tumor spindle cells appeared strongly positive for CD34 (Fig. 1C), and moderately for beta-catenin. Moreover, they were negative for pancytokeratins AE1 and AE3, EMA, CD117, desmin, smooth muscle actin, and S-100 protein, with no immunoexpression of c-kit (Fig. 1D).

\section{DISCUSSION}

The 40-old-woman here reported had an asymptomatic benign SFT, with $3 \mathrm{~cm}$ of diameter, in the pancreatic body. The tumor cells were positive for CD34 and betacatenin, and negative for c-kit. The diagnosis of SFT relied upon histological features plus immunodetection of CD34 ${ }^{1-9}$, and absence of immunoexpression of c-kit. These data ruled out the hypothesis of gastrointestinal stromal tumor ${ }^{6-8}$. Rakheja et al also described positive staining for beta-catenin in twelve cases of non-pancreatic SFT (one was malignant), and suggested that the relationship between immunoistochemical features and clinical behavior of these tumors should be cleared ${ }^{10}$. Similar to the present case, they found a pure membranous staining pattern of beta-catenin in two (17\%) of the benign SFTs, which were located in the eyelid and omentum ${ }^{10}$. Although the staining patterns of beta-catenin are variable in SFTs, both cytoplasmic and membranous locations are normal, while the nuclear, accumulation is abnormal $^{10}$. Differential diagnosis of SFT includes non-epithelial tumors: leiomyosarcoma, liposarcoma, fibrosarcoma, fibrous histiocytoma, hemangioendothelioma, hemangiopericytoma, hemangioma, lymphangioma, islet cell tumor, paraganglioma, neuroectodermal tumor, and schwannoma $a^{3,5,6,8,9}$. 


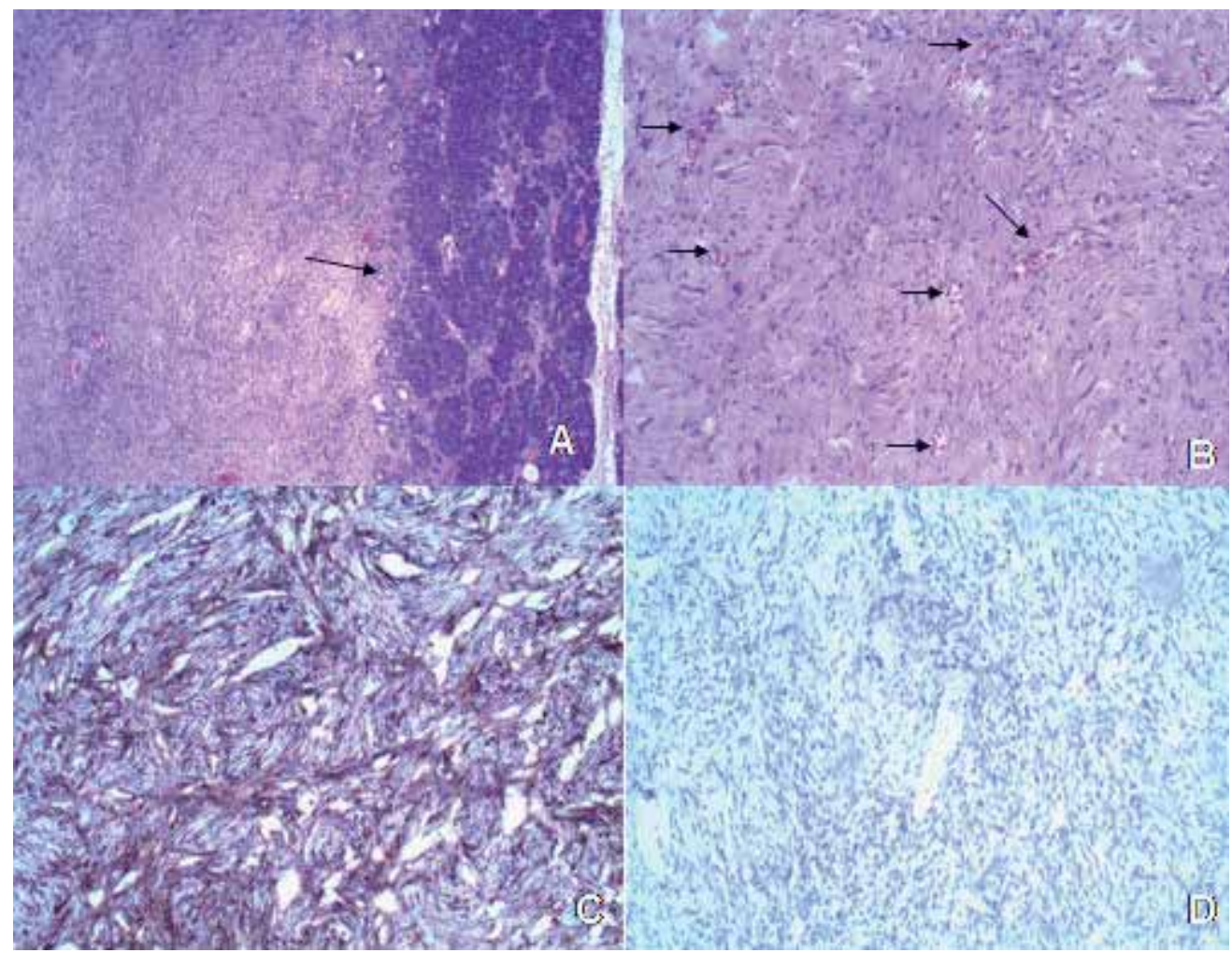

Figure 1A. Clear limits (arrow) between the fibrous tumor and the normal pancreas (HE, 40x).

Figure 1B. Hyalinized fusocellular tumor showing a vascularized (arrows) stroma (HE, 100x).

Figure 1C. Immunoexpression of CD34.

Figure 1D. Lack of immunoexpression of c-kit (CD117).

In this patient, the finding of typical pathological features of SFT of the pancreas ruled out those hypotheses The solid tumor was well demarcated from the normal pancreas, showing a patternless architecture composed by bland spindle cells arranged in fascicles alternating with dense hyalinized areas. Dilated vascular channels mimicking hemangiopericytoma were focally distributed ${ }^{1-9}$. Cellular atypias, mitosis and necrosis were absent, and normal acini were surrounding the tumor.

Statistical data about SFT of the pancreas showed few changes after including findings from the present case study (Ta- ble 1). Nine out of ten patients were women (90\%), and $60 \%$ were asymptomatic. The mean age of the patients was $54.6( \pm 12.3)$ years, and the median age was 54.5 (40 to 78 ) years. More often ( $60 \%$ of cases), the mass was in the body of the pancreas, with the greatest diameter ranging between 2 and $13 \mathrm{~cm}$ [mean of $4.9( \pm 3.4) \mathrm{cm}$, and a median of $3 \mathrm{~cm}$ ]. Although all these SFTs of the pancreas had benign characteristics, larger series of cases with longstanding follow-up are necessary to better clear their eventual malignant potential ${ }^{9}$. Additionally, the clinical significance of b-catenin staining in SFTs is not totally understood ${ }^{10}$. 
Table 1. Comparative data of ten patients with solitary fibrous tumors of the pancreas

\begin{tabular}{|c|c|c|c|c|c|}
\hline Authors (year) & Gender/age & Symptoms & Site & Diam & Immunostaining $(+)$ \\
\hline Lüttges $^{6}(1999)$ & F/ 50 years & Absent & Body & $5.5 \mathrm{~cm}$ & CD34, CD99, bcl-2,vim \\
\hline Chatti $^{1}(2006)$ & M/ 41 years & Abd pain & Body & $13 \mathrm{~cm}$ & CD34, CD99, bcl-2, vim \\
\hline $\operatorname{Gardini}^{3}(2007)$ & F/ 62 years & Abd pain & Head & $2.5 \mathrm{~cm}$ & CD34, CD99, bcl-2, vim \\
\hline Miyamoto $^{7}(2007)$ & F/ 41 years & Abd pain & Body & $2 \mathrm{~cm}$ & CD34, bcl-2 \\
\hline Kwon $^{5}(2008)$ & F/ 54 years & Absent & Body & $7.6 \mathrm{~cm}$ & CD34, CD99,vim \\
\hline Srinivasan $^{8}(2008)$ & F/ 78 years & Back pain & Body & $4.5 \mathrm{~cm}$ & CD34, CD99, bcl-2, vim \\
\hline Chetty $^{2}$ (2009) & F/ 67 years & Absent & Head & $2.6 \mathrm{~cm}$ & CD34, CD99, bcl-2 \\
\hline Ishiwatari $^{4}$ (2009) & F/ 58 years & Absent & Head & $3 \mathrm{~cm}$ & CD34, bcl-2 \\
\hline Sugawara $^{9}(2010)$ & F/ 55 years & Absent & Head & $7 \mathrm{~cm}$ & CD34 \\
\hline Santos LAM (*) & F/ 40 years & Absent & Body & $3 \mathrm{~cm}$ & CD34, $\beta$-catenin \\
\hline
\end{tabular}

F: female; M: male; Abd: abdominal; Diam: greatest diameter; vim: vimentin.

*This case study.

We believe that case studies contribute to better awareness about scarcely reported conditions.

\section{REFERENCES}

1. Chatti K, Nouira K, Ben Reguigua M, Bedioui H, OuESLATI S, LAABIDI B et al. [Solitary fibrous tumor of the pancreas. A case report]. Gastroenterol Clin Biol 2006; 30: 317-319.

2. Chetty R, Jain R, Serra S. Solitary fibrous tumor of the pancreas. Ann Diagn Pathol 2009; 13: 339-343.

3. Gardini A, Dubini A, Saragoni L, Padovani F, GarCEA D. [Benign solitary fibrous tumor of the pancreas: a rare location of extra-pleural fibrous tumor. Single case report and review of the literature]. Pathologica 2007; 99: 15-18.

4. Ishiwatari H, Hayashi T, Yoshida M, Kuroiwa G, SAto Y, Kobune M et al. [A case of solitary fibrous tumor of the pancreas]. Nippon Shokakibyo Gakkai Zasshi 2009; 106: 10781085.
5. Kwon HJ, Byun JH, Kang J, Park SH, Lee MG. Solitary fibrous tumor of the pancreas: imaging findings. Korean J Radiol 2008; 9: S48-51.

6. Lüttges J, Mentzel T, HüBner G, KlöPPEl G. Solitary fibrous tumour of the pancreas: a new member of the small group of mesenchymal pancreatic tumours. Virchows Arch 1999; 435: 37-42.

7. Miyamoto H, Molena DA, Schoeniger LO, HaODONG XU. Solitary fibrous tumor of the pancreas: a case report. Int J Surg Pathol 2007; 15: 311-314.

8. SRInivasan VD, Wayne JD, Rao MS, Zynger DL. Solitary fibrous tumor of the pancreas: case report with cytologic and surgical pathology correlation and review of the literature. JOP 2008; 9: 526-530.

9. Sugawara Y, Sakai S, Aono S, Takahashi T, Inoue T, Oнта K et al. Solitary fibrous tumor of the pancreas. Jpn J Radiol 2010; 28: 479-482.

10. RaKheja D, Molberg KH, Roberts CA, JaISWAL VR. Immunohistochemical expression of beta-catenin in solitary fibrous tumors. Arch Pathol Lab Med 2005; 129: 776-779. 